Abstracta Iranica Abstracta Iranica

Revue bibliographique pour le domaine irano-aryen

Volume 40-41 | 2019

Comptes rendus des publications de 2017-2018

\title{
Adam Benkato. Āzandnāmē. An edition and literary- critical study of the Manichaean Sogdian Parable Book
}

\section{Antje Wendtland}

\section{OpenEdition}

1 Journals

\section{Electronic version}

URL: http://journals.openedition.org/abstractairanica/50536

DOI: 10.4000/abstractairanica.50536

ISBN: 1961-960X

ISSN: 1961-960X

Publisher:

CNRS (UMR 7528 Mondes iraniens et indiens), Éditions de l'IFRI

Electronic reference

Antje Wendtland, "Adam Benkato. Āzandnāmē. An edition and literary-critical study of the Manichaean Sogdian Parable Book", Abstracta Iranica [Online], Volume 40-41 | 2019, document 4, Online since 30 December 2019, connection on 19 April 2021. URL: http://journals.openedition.org/abstractairanica/ 50536 ; DOI: https://doi.org/10.4000/abstractairanica.50536

This text was automatically generated on 19 April 2021.

Tous droits réservés 


\title{
Adam Benkato. Āzandnāmē. An edition and literary-critical study of the Manichaean Sogdian Parable Book
}

\author{
Antje Wendtland
}

\section{REFERENCES}

Adam Benkato. Āzandnāmē. An edition and literary-critical study of the Manichaean Sogdian Parable Book. Wiesbaden: Dr. Ludwig Reichert Verlag, 2017, 210 p. (Beiträge zur Iranistik 42)

1 The work to be presented here is a re-edition of the Manichaean Parable Book (Āzandnāmē) published by Werner Sundermann, Ein manichäisch-soghdisches Parabelbuch (Berliner Turfantexte 15, 1985), supplemented by new material which has been found since. The book consists of two parts. The first part contains chapters on the discovery of the manuscripts, the script, orthography and grammar of the texts, and the translation with commentary. A glossary and a very useful list of Manichaean parables in Iranian languages and their publications are given the end of the book.

2 Parts of three parables have been preserved, one very fragmentary (Parable of a Judge) and two longer but also incomplete ones (Parable of the Religion and the Ocean and Parable of two Snakes).

3 The second part of the book is dedicated to an extensive textual analysis and a very detailed account of the interpretation of Manichaean parables and their meaning for the study of Buddhist literature. In particular, the analysis of the Parable of the Religion and the Ocean as an adaptation of a Buddhist model, its comparison and the explication of its Manichaean reinterpretation is of great value for Manichaean studies.

Only a few minor points: In Sogdian $\gamma r y w$ means "body, self" and can be used as a reflexive. In some text editions the translation "soul" is found. But as there is a stark contrast in the Manichaean religion between the human body (the result of mixture of 
good and evil) and the soul, it is quite unlikely that a word is used referring to both. It is rather a misunderstanding due to MP gryw. The Sogdian word for "soul" is $r w$ ' $n$ and occurs in the Āzandnāmē, in the Parable of the Snakes (cf. 181, 191, 194, 200). In 133 rty $n w k r$ ZKw $\gamma r y w H$ " $\beta r y n(') n t$ B. translates "Then they praise the soul", following an emendation by N. Sims-Williams; he notes that here the texts diverges in respect to the otherwise used $r w$ ' $n H$ for "soul". Sundermann reads the verb differently, as "Bryncnt, "Und nun *veredeln sie sich selbst". Only three lines above $\gamma r y w H$ is used as a reflexive.

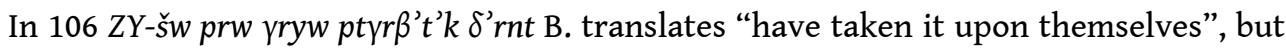
in the wordlist "soul?" is found. In an incomplete line in the fragmentary Parable of a Judge, ANj 30, B. considers translating $\gamma r^{\prime} y w y$ as "soul", although B. states that the context is lacking. The translation of $x y p \delta$ as "my, your, his, their, own" instead of just "own" is a bit misleading, although, in its possessive meaning it can be translated accordingly, but this is attributed to the possessives in English, cf. Russian свой; $x w n w x$, rather "the one who, that which" than just "that".

\section{AUTHORS}

\section{ANTJE WENDTLAND}

Allemagne 